\title{
The use of celebrity athletes as endorsers: views of the New Zealand general public
}

\author{
Keywords \\ athlete \\ endorsement \\ advertising
}

\section{Jan Charbonneau}

Lecturer, Department of Marketing, Massey University

Palmerston North, New Zealand

Tel: +64 (0) 63505588

Fax: +64 (0) 63502260

Email: j.charbonneau@massey.ac.nz

\section{Ron Garland}

Associate Professor, Department of Marketing, Waikato Management School, Waikato University, Hamilton, New Zealand

\section{Peer reviewed}

\section{Executive summary}

New Zealand companies have a long history of using professional athletes as endorsers in their promotional campaigns. Celebrity endorsement literature suggests transfer of positive image between the celebrity/athlete and product, service or cause endorsed.

The purpose of this research was to assist sports marketing managers and advertising agencies in matching athletes with products. Following on from athlete endorsement research conducted with tertiary

\begin{abstract}
Matching celebrity athletes with potential endorsement opportunities is often difficult. Yet there are easy-touse survey-based methods available. Based on a survey of the general public in New Zealand, this study uses both Ohanian's source-credibility scale and a constant-sum scale to help brand managers, player agents and advertising practitioners select good celebrity athlete-product fit. Four New Zealand athletes (two males and two females) and several products were included in the test. Results show that the female celebrity athletes outperformed their male counterparts as potential endorsers. Use of Ohanian's multi-attribute scale yields a level of richness and insight, prompting us to advocate the use of both scales in the pursuit of endorser-product congruences.
\end{abstract}

education students (Garland \& Ferkins, 2003), the views of the New Zealand general public relative to athlete endorsement were solicited. Ohanian's (1990) 15 -item source-credibility scale and the constant-sum scale were used to measure potential endorsement fit for four sporting personalities: Bernice Mene (retired captain, national netball team); Sarah UImer (2004 Olympic gold medallist, cycling); Justin Marshall (All Black rugby, most capped halfback); and 
Stephen Fleming (captain, national cricket team). Confirmatory factor analysis was conducted to validate the Ohanian scale as an appropriate testing instrument for endorsement fit. The Ohanian scale was used to test each athlete's credibility as endorser of a sports drink, with the constant-sum scale used to test their endorsement fit for a sports drink, bottled water, deodorant, honey and a bank account.

Overall, the female athletes scored best on both scales and for all products except the bank account, making them good 'all rounders' for product endorsements. Stephen Fleming and Bernice Mene, both team captains, received comparable scores for endorsement of bank accounts, suggesting perhaps a public perception of their leadership and authority.

\section{Introduction}

Celebrity and celebrity athlete endorsements have long attracted the interest of practitioners, students and researchers (Brooks \& Harris, 1998). For this paper, a celebrity athlete endorser is a publicly recognised sports star who uses that public recognition to help another (usually a corporate client) bolster the image of or sell specific goods and services.

Celebrities and celebrity athletes provide benefits that unknown endorsers cannot. Celebrities 'cut through' advertising clutter, hold viewer attention (Charbonneau \& Garland, 2005) and transfer positive qualities such as physical attractiveness and likeability to the brand (Ohanian, 1990). They contribute to brand name recognition/recall and assist in the development of credible, distinct brand personalities (Erdogan \& Kitchen, 1998). Athletes provide particularly compelling endorsements for products that have contributed to their sporting performance and success (Dyson \& Turco, 1997; Stone et al, 2003). However, with these benefits come risks. Increased celebrity attention may lead to brand overshadowing (Erdogan \& Kitchen, 1998). Controversy involving the endorser can lead to corporate embarrassment and transfer of negative attitudes to the brand (Till, 2001;
Pornpitakpan, 2003). Celebrities endorsing multiple products risk overexposure, lessening the impact and distinctiveness of each product relationship and diminishing consumer perceptions of celebrity credibility and likeability (James \& Ryan, 2001; Garland \& Ferkins 2003). Celebrity athletes face the constant risk of injury, which would reduce visibility and performance and thereby endorsement potential (Irwin et al, 2002).

While there are inherent risks, the widespread continued practice of using celebrities and celebrity athletes signals that marketers believe the risks are worth taking (Dyson \& Turco, 1998), "even though research findings are equivocal about the ability of celebrities to stimulate actual purchase behaviour" (Erdogan \& Kitchen 1998, p.17).

Much research effort has focused on developing selection criteria; however, there is little agreement as to most the significant dimensions (Erdogan, 1999). The Source Credibility Model suggests that message effectiveness depends on endorser perceived credibility (Ohanian, 1990, 1991; Shank, 2005). According to the Source Attractiveness Model, message effectiveness depends on similarity, likeability and familiarity between source and receiver (Shank, 2005). According to the Product Match-up Hypothesis, effective advertising results when the messages conveyed by celebrity image are compatible with product image (Pornpitakpan, 2003). The Meaning Transfer Model maintains that the cultural meanings celebrity endorsers possess, such as status and lifestyle, transfer to products endorsed (McCracken, 1989).

Considerable attention has been paid to the consumer side, with comparatively little attention paid to criteria practitioners actually use to make endorsement decisions. Four main studies have explored advertising practitioners' perspectives towards celebrity endorsements in the United States, the United Kingdom and New Zealand: Miciak \& Shanklin (1994); Erdogan \& Baker (1999,2000); Erdogan et al (2001); and Charbonneau \& Garland (2005). Only the latter specifically investigated celebrity athlete 
endorsers. According to New Zealand advertising practitioners, creating a campaign around an endorser - celebrity or athlete - is usually initiated by the agency rather than the client (Charbonneau \& Garland, 2005). Therefore there is a need for tools such as general public testing instruments to help agencies make informed selection decisions.

The results of the four studies showed that while a similar list of factors were considered when selecting an endorser, the priority given to each was dependent on specific campaign objectives. For instance, Charbonneau \& Garland (2005) found that advertising practitioners in New Zealand placed greater importance on risk of negative publicity and hiring costs; by contrast, much of the consumer literature placed greater importance on credibility and trustworthiness. This may reflect the increasing costs of celebrity endorsements and the intense media interest in celebrity actions. Notably, all four studies emphasised the importance of celebrity-audience match-up and celebrity-product match-up.

\section{Objectives and methodology}

In a pilot study, Garland \& Ferkins (2003) tested Ohanian's (1990) 15-item source-credibility scale with a sample of New Zealand tertiary education students. Ohanian's scale incorporates two themes from the existing literature: source credibility (expertise and trustworthiness) and source attractiveness (familiarity, likeability and similarity). Confirmatory factor analysis suggested that Ohanian's scale was psychometrically appropriate for measuring celebrity athletes' source credibility and attractiveness, making it an appropriate instrument for testing 'endorsement fit'.

The first objective of this study was to validate the appropriateness of Ohanian's scale with the New Zealand general public. The second objective was to assess four celebrity athletes for their endorsement potential across several unbranded products using both the Ohanian scale and a constant-sum scale. Unbranded products were used to eliminate branding effects.

A postal survey was conducted in New Zealand in May 2004, with participants randomly selected from the New Zealand electoral register. One reminder was sent. The final sample of 392 adult New Zealanders represented a $46 \%$ response rate, with sampling error of $4.9 \%$ at $95 \%$ confidence. The sample was $57 \%$ female and $43 \%$ male, with the age breakdown relatively aligned with the New Zealand 18 years + population parameters $(7 \%<25 ; 36 \% 25-44$; 37\% 45-64; 20\% 65+).

Respondents were asked for basic demographic information as well as familiarity with each athlete and interest in, participation in and purchase of merchandise for the sport played by each of the four celebrity athletes. The four athletes had been selected from a large number of New Zealand celebrity athletes using two focus groups.

\section{Results and discussion}

Respondents' involvement in celebrity athletes' sports Overall, respondents were reasonably familiar with each of the athletes selected (see Table 1). While Bernice Mene is the only retired athlete, she remains in the public eye as a spokesperson for health issues. Interest in the particular sport of the celebrity athlete roughly follows the overall popularity of the sport among New Zealanders, with rugby being most popular and cycling least popular. Survey respondents were spectators rather than players/administrators of each sport and low purchasers of each sport's merchandise, other than rugby.

\section{Appropriateness of Ohanian's scale as a testing instrument}

The confirmatory factor analysis (see Table 2) showed that the New Zealand general public data fitted Ohanian's 15-attribute, three-dimensional source credibility scale rather well. There was a distinct break 
TABLE 1 Involvement in celebrity athletes' sports

\begin{tabular}{l|c|c|c|c} 
& $\begin{array}{c}\text { FAMILIARITY } \\
\text { ATHLETE (\%) }\end{array}$ & $\begin{array}{c}\text { INTEREST } \\
\text { IN SPORT (\%) }\end{array}$ & $\begin{array}{c}\text { PARTICIPATION } \\
\text { IN SPORT (\%) }\end{array}$ & $\begin{array}{c}\text { MERCHANDISE } \\
\text { PURCHASE (\%) }\end{array}$ \\
\hline BERNICE MENE (NETBALL) & 89 & 23 & 7 & 7 \\
\hline JUSTIN MARSHALL (RUGBY) & 81 & 44 & 6 & 22 \\
\hline SARAH ULMER (CYCLING) & 82 & 7 & 4 & 4 \\
\hline STEPHEN FLEMING (CRICKET) & 81 & 31 & 8 & 8 \\
\hline
\end{tabular}

TABLE 2 Confirmatory factor analysis on Ohanian's (1990) scale

\section{OHANIAN'S FACTORS \& ATTRIBUTES}

\begin{tabular}{|c|c|c|c|c|}
\hline \multirow{3}{*}{ ATTRACTIVENESS } & \\
\hline & MENE & MARSHALL & ULMER & FLEMING \\
\hline & & & & \\
\hline UNATTRACTIVE - ATTRACTIVE & .80 & .77 & .74 & .80 \\
\hline NOT CLASSY - CLASSY & .75 & .69 & .79 & .75 \\
\hline UGLY - BEAUTIFUL & .73 & .82 & .81 & .82 \\
\hline PLAIN - ELEGANT & .82 & .82 & .84 & .82 \\
\hline NOT SEXY - SEXY & .78 & .82 & .85 & .88 \\
\hline EIGENVALUES FOR ATTRACTIVENESS FACTOR & 1.36 & 1.65 & 1.29 & 1.40 \\
\hline CRONBACH'S ALPHA & .90 & .89 & .93 & .93 \\
\hline \multicolumn{5}{|l|}{ TRUSTWORTHINESS } \\
\hline NOT DEPENDABLE - DEPENDABLE & .65 & .84 & .77 & .80 \\
\hline DISHONEST - HONEST & .89 & .91 & .89 & .87 \\
\hline UNRELIABLE - RELIABLE & .90 & .90 & .90 & .89 \\
\hline INSINCERE - SINCERE & .89 & .89 & .90 & .88 \\
\hline UNTRUSTWORTHY - TRUSTWORTHY & .90 & .90 & .89 & .88 \\
\hline EIGENVALUES FOR TRUSTWORTHINESS FACTOR & 7.67 & 8.15 & 8.98 & 9.11 \\
\hline CRONBACH'S ALPHA & .96 & .97 & .98 & .97 \\
\hline \multicolumn{5}{|l|}{ EXPERTISE } \\
\hline NOT AN EXPERT - EXPERT & .81 & .89 & .90 & .91 \\
\hline INEXPERIENCED - EXPERIENCED & .83 & .86 & .86 & .86 \\
\hline UNKNOWLEDGEABLE - KNOWLEDGEABLE & .87 & .87 & .91 & .89 \\
\hline UNQUALIFIED - QUALIFIED & .86 & .90 & .90 & .91 \\
\hline UNSKILLED - SKILLED & .85 & .89 & .90 & .90 \\
\hline EIGENVALUES FOR EXPERTISE FACTOR & 2.61 & 2.54 & 2.69 & 2.45 \\
\hline CRONBACH'S ALPHA & .93 & .96 & .96 & .97 \\
\hline VARIANCE EXPLAINED OVERALL (\%) & 77 & 82 & 86 & 86 \\
\hline
\end{tabular}


TABLE 3 Endorsement of an unbranded sports drink

\begin{tabular}{l|c|c|c|c}
$\begin{array}{l}\text { OHANIAN (1990) } \\
\text { DIMENSIONS }\end{array}$ & BERNICE MENE & JUSTIN MARSHALL & SARAH ULMER & STEPHEN FLEMING \\
\hline SAMPLE SIZE & $(326)$ & $(317)$ & $(316)$ & $(293)$ \\
\hline ATTRACTIVENESS & $25.3^{*}$ & 21.3 & $25.6^{*}$ & 23.2 \\
\hline TRUSTWORTHINESS & $29.9^{*}$ & 25.8 & 28.3 & 28.1 \\
\hline EXPERTISE & 26.4 & 25.1 & 27.0 & 26.0 \\
\hline GRAND MEAN & $81.6^{*}$ & 72.2 & $80.9^{*}$ & 77.3 \\
(TOTAL) & $27.2^{*}$ & 24.1 & $27.0^{*}$ & 25.8
\end{tabular}

Each dimension made up of 5 attributes on 7-point semantic differential scale

* ANOVA results (95\% confidence on 2 tailed test)

after three factors on Cattell's scree plot for each athlete, and between $77 \%$ and $86 \%$ of the variance was explained for each athlete by the three factors (attractiveness, trustworthiness and expertise). Closer examination of the eigenvalues showed that heaviest contribution is from the expertise factor, followed by trustworthiness and then attractiveness. When varimax rotation was invoked, convergence occurred after four iterations. In only two instances - dependability (Mene: .65) and classiness (Marshall: .69) - were factor loadings below the generally accepted criterion of .70 (Hair et al, 2002). These were such minor infractions (3\% of the data and just below the acceptability criterion) that we ignored them. Similarly, internal consistency for attributes upon factors is "meritorious" (Norusis, 1998) using Cronbach's Alpha coefficient of reliability. Considering construct validity and reliability, Ohanian's scale is judged to be an appropriate testing instrument for endorsement fit and can be used with the general public.

\section{Endorsement of unbranded sports drink - Ohanian scale results}

An unbranded sports drink was selected for its obvious sporting link. Respondents who were not familiar enough with any of the celebrity athletes to assess them on Ohanian's scale skipped that part of the survey. Once pairwise deletion of missing data for the scale analysis was carried out, sample sizes reduced from a maximum of $n=392$ for each athlete to $n=326$ for Mene, $n=317$ for Marshall, $n=316$ for Ulmer and $n=293$ for Fleming.

Bernice Mene is the celebrity athlete most preferred for endorsing an unbranded sports drink, with Sarah Ulmer a close second (see Table 3). While Mene was second to UImer on the attractiveness dimension, her ratings on the trustworthiness dimension clinched her overall 'best fit' position. The females outperformed the males in terms of attractiveness. Mene was perceived as most trustworthy overall, with Marshall being least so. Not surprisingly, all athletes were judged as 
TABLE 4 Constant-sum scale results

\begin{tabular}{l|c|c|c|c|c} 
PRODUCT & $\begin{array}{c}\text { SPORTS } \\
\text { DRINK (\%) }\end{array}$ & $\begin{array}{c}\text { BOTTLED } \\
\text { WATER (\%) }\end{array}$ & $\begin{array}{c}\text { DEODORANT } \\
(\%)\end{array}$ & $\begin{array}{c}\text { HONEY } \\
(\%)\end{array}$ & $\begin{array}{c}\text { BANK } \\
\text { ACCOUNT (\%) }\end{array}$ \\
\hline SAMPLE SIZE & $(293)$ & $(293)$ & $(293)$ & $(293)$ & $(293)$ \\
\hline MENE & 27 & 27 & 29 & 19 & $21^{*}$ \\
\hline MARSHALL & 26 & 25 & 23 & $30^{*}$ & 23 \\
\hline ULMER & $30 *$ & $31^{*}$ & 27 & 20 & 23 \\
\hline FLEMING & 23 & 23 & 26 & 100 & $2{ }^{*}$ \\
\hline TOTAL & 100 & 100 & 100 & 100 \\
\hline
\end{tabular}

* ANOVA results (95\% confidence on 2 tailed test)

experts relative to endorsing a sports drink. Grouping attributes under dimensions and deriving group means as well as an overall global mean can be controversial. It assumes that each attribute has a unitary value and that may not always be the case. However, the confirmatory factor analysis reported above indicates clearly that the 15 attributes of Ohanian's scale are valid and reliable measures of the three dimensions of source credibility. Results in Table 3 show that the distances between the means for each athlete on each dimension suggest that there are real differences in the perceptions of respondents as to which athlete is the best fit for endorsing an unbranded sports drink. The message for marketers and advertisers - seriously consider the females!

\section{Endorsement of products - constant-sum results}

Each product tested was selected for a specific reason. The sports drink was selected for its obvious sporting link and use by celebrity athletes. Deodorant was selected as it is a personal branded product that often uses athlete endorsers in promotional campaigns. The bank account, as a service, was included to test for authority and leadership beyond athletic prowess. Bottled water and honey represented generally perceived gender-neutral products.

As can be seen in Table 4, when athletes were evaluated (by respondents who are familiar with them) relative to each other, Sarah UImer was seen as the best fit as endorser for both the unbranded sports drink and the bottled water. Bernice Mene and Stephen Fleming, both team captains, were judged the best fit as endorsers for a bank account, suggesting spillover from their on-field leadership. Mene appears a better fit for deodorant, with either of the female athletes a good fit for honey.

Considering the Ohanian source credibility results in conjunction with those generated by the constant-sum scale allows advertisers to 'position' celebrity athletes to better advantage.

\section{Limitations and conclusions}

Due to copyright issues and cost factors, descriptions of celebrity athletes were used rather than photographs, perhaps explaining the $20 \%$ non-awareness. The products selected were gender-neutral, but results may be different if testing gender-specific products.

The survey was conducted in May 2004, prior to the Olympics and the All Blacks 2004 campaign but during the Super 12 rugby competition and Black Caps cricket tour to England. Given Ulmer's Olympic medal and Marshall's All Black performance, their scores might have been higher if the survey had been conducted later in the year. 
Whatever scale is used, benefits must be balanced with limitations. For example, Ohanian's scale is American derived and validated, raising the perennial question of cross-cultural applicability, and has the further issue of assumption of equal influence per attribute, mentioned earlier. Both of these reservations, however, have been addressed and are shown to be of minimal influence in the results discussed above.

In this survey the female athletes, Mene and Ulmer, outperformed their male counterparts, Marshall and Fleming, coming through as particularly good 'allrounders' for product endorsement. The multi-item approach provided by the Ohanian scale results provides advertising agencies with insights into how to present celebrity athletes. For example, an advertisement featuring Bernice Mene would be well advised to capitalise on her trustworthiness.

According to New Zealand advertising practitioners, the use of celebrity athletes as endorsers is not generally their first option (Charbonneau \& Garland, 2005). However, once a decision has been made to proceed with an endorsement, practitioners are faced with the decision of who to select from the growing stable of celebrity athletes. Our research shows that scales such as Ohanian's and constant-sum can be useful as testing instruments for use with the general public when evaluating a range of athletes as potential endorsers.

(c) 2006 International Marketing Reports

\section{Biographies}

Jan Charbonneau is a lecturer in the Department of Marketing, Massey University, Palmerston North, New Zealand, and conducts research in electronic marketing, sports marketing and market research. She has published in journals including the International Journal of Sports Marketing \& Sponsorship.

Ron Garland is an associate professor in the Department of Marketing, Waikato Management School, University of Waikato, Hamilton, New Zealand. He conducts research in consumer behaviour, market research and sports marketing. He has published in journals including the International Journal of Sports Marketing \& Sponsorship. 


\section{References}

Brooks, C.M. \& Harris, K. (1998) Celebrity athlete endorsement; an overview of the key theoretical issues, Sport Marketing Quarterly 7 (2), 34-44.

Charbonneau, J. \& Garland, R. (2005) Talent, looks or brains? New Zealand advertising practitioners' views on celebrity and athlete endorsers, Marketing Bulletin 16 (3).

Dyson, A. \& Turco, D. (1998) The state of celebrity endorsement in sport, Cyber-Journal of Sport Marketing 2 (1). Accessed 30 May 2005 at: http://www.ausport.gov.au/fulltext/1998/cjsm

Erdogan, B. (1999) Celebrity endorsement: a literature review, Journal of Marketing Management 15 (4), 291-314.

Erdogan, B. \& Baker, M. (1999) Celebrity endorsement: advertising agency managers' perspective, Cyber Journal of Sport Marketing, 3(3). Accessed 30 May 2005 at: http://www.ausport.gov.au/fulltext/1999/cjsm

Erdogan, B. \& Baker, M. (2000) Towards a practitioner-based model of selecting celebrity endorsers, International Journal of Advertising 19 (1), 25-42.

Erdogan, B. \& Kitchen, P. (1998) Getting the best out of celebrity endorsers, Admap (April, 17-20).

Erdogan, B., Baker, M. \& Tagg, S. (2001) Selecting celebrity endorsers: the practitioner's perspective, Journal of Advertising Research 41 (3), 39-48.

Garland, R. \& Ferkins, L. (2003) Evaluating New Zealand sports stars as celebrity endorsers: intriguing results, Proceedings of ANZMAC Conference, University of South Australia, Adelaide (December), CD-ROM, 122-129.

Hair, J.F., Anderson, R.E., Tatham, R.L. \& Black, W.C. (2002) Multivariate data analysis (5th edn). Upper Saddle River, NJ: Prentice Hall.
Irwin, R., Sutton, W. \& McCarthy, L. (2002) Sports promotion and sales management. Champaign, Illinois: Human Kinetics.

James, K. \& Ryan, M. (2001) Attitudes to female sports stars as endorsers, Proceedings of ANZMAC Conference, Massey University, Auckland (November), CD-ROM, 1-8.

McCracken, G. (1989) Who is the celebrity endorser? Cultural foundations of the endorsement process, Journal of Consumer Research 16 (3), 310-321.

Miciak, A. \& Shanklin, W. (1994) Choosing celebrity endorsers, Marketing Management 3 (3), 50-59.

Norusis, M.J. (1998) SPSS/PC and V2.0 Base Manual. Chicago: SPSS Inc.

Ohanian, R. (1990) Construction and validation of a scale to measure celebrity endorsers' perceived expertise, trustworthiness, and attractiveness, Journal of Advertising 19 (3), 39-52.

Ohanian, R. (1991) The impact of celebrity spokespersons' perceived image on consumers' intention to purchase, Journal of Advertising Research 13 (1), 46-55.

Pornpitakpan, C. (2003) Validation of the celebrity endorsers' credibility scale: evidence from Asians, Journal of Marketing Management 19(1/2), 179-195.

Shank, M. (2005) Sports marketing: a strategic perspective (3rd edn). New Jersey: Prentice Hall.

Stone, G., Joseph, M. \& Jones, M. (2003) An exploratory study on the use of sports celebrities in advertising: a content analysis, Sport Marketing Quarterly 10 (1), 35-42.

Till, B. (2001) Managing athlete endorser image: the effect of endorsed product. Sport Marketing Quarterly 10 (1), 35-42. 
Copyright of International Journal of Sports Marketing \& Sponsorship is the property of International Marketing Reports Ltd. and its content may not be copied or emailed to multiple sites or posted to a listserv without the copyright holder's express written permission. However, users may print, download, or email articles for individual use. 